\title{
EVALUATION OF FODDER BEAN WASTE UTILIZATION FOR ENERGY PURPOSES
}

\author{
Aleksandra Minajeva ${ }^{1,2}$, Algirdas Jasinskas ${ }^{1}$, Kestutis Romaneckas ${ }^{1}$, Aivars Aboltins ${ }^{3}$ \\ ${ }^{1}$ Aleksandras Stulginskis University, Lithuania; ${ }^{2}$ Vilnius College of Technologies and Design, \\ Lithuania; ${ }^{3}$ Latvia University of Life Sciences and Technologies, Latvia \\ mkupidonas@gmail.com, algirdas.jasinskas@asu.lt,kestas.romaneckas@asu.lt, \\ aivars.aboltins@inbox.lv
}

\begin{abstract}
The present paper provides the research results of fodder beans, which were grown in the Lithuanian climatic zone, cultivation, harvesting, after harvesting and threshing received waste utilization for energy purposes. Investigations were carried out in the fields and laboratories of the Aleksandras Stulginskis University (ASU) in 2015-2017; the technological-technical means of these plants processing, biofuel pellet production and usage for energy purposes were investigated at the Institute of Agricultural Engineering and Safety (ASU), and, at the Lithuanian Energy Institute, the pellet physical and thermal properties, when plant pellets were burned the pellet calorific value, ash content and harmful emissions to the surrounding atmosphere - were determined. The research results of technological-technical parameters of fodder bean waste preparation for pressed (granulated) solid biofuel and produced chaff, and mill quality were presented in justice of the use of the drum chopper and hammer milling equipment preparing mill fractional composition and mill pelleting quality. The physical-mechanical properties of the investigated fodder bean waste pellet moisture content, density, ash content and pellet calorific value were determined and presented. Investigated pellet moisture content ranged from $8.9 \%$ to $9.8 \%$, and the determined pellet density was very high and reached $1311.40 \pm 64.67 \mathrm{~kg} \cdot \mathrm{m}^{-3} \mathrm{DM}$ (dry matter). The determined ash content varied from 3.9 to $7.0 \%$ and the average dry mass calorific value reached $17.0 \mathrm{MJ} \cdot \mathrm{kg}^{-1}$. Also, harmful emissions, when these fodder bean waste pellets were burned, were investigated. The received concentration of carbon monoxide was $1900-2020 \mathrm{ppm}$; the quantity of carbon dioxide varied from 4.1 to $5.2 \%$; emissions of nitrogen oxide varied from $146.1 \mathrm{ppm}$ to $164.1 \mathrm{ppm}$.
\end{abstract}

Keywords: fodder bean, waste, utilisation, solid biofuel, pellets, properties.

\section{Introduction}

The growing dependence of Lithuania on energy imports, issues of climate change and rise in energy prices are increasingly raising discussion about alternative energy sources. Implementation of sustainable development strategy becomes the priority of the energy sector in the world. The concept of sustainable development is based on three equally important components: environmental protection, economic development and social development. However, the use of plants - especially raw food materials - for the production of energy promotes the concern about the overall supply of food. The main argument against the promotion of biomass use is the limited availability of land resources and farmland. The Article 1.2.3 of the Resolution of the General Assembly Transforming Our World adopted in the $70^{\text {th }}$ Session of the United Nations on September 25, 2015, anticipates the decrease in global food waste per capita at the retail and consumer level in half by 2030, as well as the reduction of losses in food production and supply chains, including post-harvest losses [1]. Thus, the use of agricultural waste for energy production becomes gradually relevant [2].

The global production of beans (fodder and food beans) is estimated at 3,398,330 tons and their harvest area is approximately $2,057,883$ ha a year [3]. The area of bean crops is growing annually in Lithuania. According to the data of the Lithuanian Department of Statistics, the yield of beans was $9.8 \%$ higher in 2017 than in 2016 and amounted to 229.8 thousand tons [4].

Beans are less susceptible to frosts and can grow at temperature of $5{ }^{\circ} \mathrm{C}$. Therefore, their seeds are sown in April. In that case, they are less prone to the plant-louse infestation and provide higher yields. Moderately and severely heavy soil, which is non-acidic and moist, with a neutral $\mathrm{pH}$ of 6-7, is the best for bean growing. The soil must be loose for its aeration to be sufficient. The most suitable preceding crop for plants of the bean family is root-crops [5]. Beans are seeded every $12-15 \mathrm{~cm}$ in rows, leaving a spacing of $45-55 \mathrm{~cm}$ between the rows. They are inserted at a depth of 6-8 $\mathrm{cm}$.

The yield is harvested in September, when pods become black. When the yield is harvested with a tractor or self-propelled combine, their vegetable waste, i.e. their above-ground parts and the debris, are often spread on the surface of the soil or, in case of high yields of plants, are moved to rows and later collected and mechanically removed from the field. One hectare yields the possible amount of 67 tons $\cdot$ ha $^{-1}$ of seeds, as well as $10-12$ tons $\cdot$ ha $^{-1}$ of leaves + stems + root dry materials which, after 
drying and processing as raw materials, can also be additionally used for the production of energy biomass. According to the amounts of by-products of agricultural crops grown in Lithuania, it is noticeable that the main by-products of beans are waste after thrashing, which make up about half of the total production. Typically, these kinds of by-products can be used to produce biofuel of the following forms: pressed bales (panels), pellets and briquettes [6]. This biofuel can be used in households for small household boilers with the capacity of 20-50 kW and centralized boiler houses [7]. There is a lack of accurate data on the utilization of these wastes for the biofuel purposes; therefore, more research on the formation and utilization of agricultural plant waste is needed [8].

The aim of this work is to investigate fodder bean waste preparation for pressed (granulated) solid biofuel and utilization for energy purposes. In order to achieve the goal, it is necessary to determine the physical-mechanical and thermal properties of produced pellets, calorific value, ash content and harmful emissions to the surrounding atmosphere by pellet burning.

\section{Materials and methods}

Biofuel from bean waste can be characterized by various physical-mechanical and thermal properties: moisture, density, compression strength, ash, heat content and harmful emissions caused by combustion of pellets. These properties are very important for preparation of raw materials for the production, transport and in generation of biofuels. It has been determined that pellets produced without additional binding materials withstand a pressure up to $22.5 \mathrm{~N} \cdot \mathrm{mm}^{-2}$. This means that without the use of binders, we shall be able to avoid the environment pollution, and these pellets shall be quite resistant to various mechanical influences. Laboratory tests are carried out to determine the resistance of granules, while the crushing strength is evaluated by the force acting upon the destruction of a pellet $[9 ; 10]$.

In the course of the experimental research, samples of vegetable waste from thrashed beans were chopped and prepared for pelleting. The process of pellet production was first developed for the livestock feed industry. It can be said, it consists of a few basic sub-processes: chopping of the raw material, milling, drying, pelleting and cooling. The first technological process of processing fodder bean waste into granular biofuel is chopping and milling [11].

The quality of plant chopping and milling. For the first step of stem chopping a drum chopper of a forage harvester Maral 125 was used [12]. Before production of biofuel pellets, the chopped mass should be milled. Retsch SM 200 mill was used for chaff milling. The milling quality (particle fractional composition) was determined using the standard methodology. The fractional composition of mill was determined using a set of $200 \mathrm{~mm}$ diameter sieves with round holes of diameters $0.25 \mathrm{~mm}$, $0.5 \mathrm{~mm}, 0.63 \mathrm{~mm}, 1 \mathrm{~mm}$ and $2 \mathrm{~mm}$. The mass remaining on the sieves was weighed, and the sample fraction percentages were calculated [13]. All tests were repeated 5 times.

Pellet production and determination of pellet physical-mechanical properties. After mill making, dry bean waste (10-12\% moisture) is moved by a conveyor to a pellet mill, where the pellets are extruded through the action of rollers acting on a perforated matrix, and then a knife cuts off pellets at the desired length. Residual moisture in the feedstock turns to steam during compression and helps lubricate the compression die. After extrusion the pellets are very hot $\left(90-100^{\circ} \mathrm{C}\right)$ and are immediately air quenched down to $25^{\circ} \mathrm{C}$. This sets up lignin and hardens the product, and contributes to maintain its quality during storage and handling [9].

For pellet production, the plant mill was granulated by a small capacity $\left(80-120 \mathrm{~kg} \cdot \mathrm{h}^{-1}\right)$ granulator with a horizontal granulator matrix; the diameter of the pellets was $6 \mathrm{~mm}$ [14]. After pellet cooling, their biometric parameters: dimensions, humidity, volume and density were evaluated. The pellet volume was determined by measuring their length and diameter (accurate to $0.05 \mathrm{~mm}$ ). Pellet weight was assessed by the KERN ABJ scales (accurate to $0.001 \mathrm{~g}$ ). The pellet biometric parameters and weights were calculated for each type of plant pellets using 10 of the granules with the average meaning error. Pellet moisture content was determined in a drying chamber oven in accordance with the standard method [15].

After determination of the pellet volume, pellet size (diameter and length) and pellet mass, the pellet density was calculated. The bulk density of pellets was also determined. Pellets were poured into a $6 \mathrm{dm}^{3}$ container, weighing and calculating the bulk density [16]. 
Determination of pellet thermal properties. Pellet calorific value, ash content and harmful emissions, when the investigated fodder bean waste pellets were burned, were determined at the Lithuanian Energy Institute, Thermal equipment research and testing laboratory in accordance with the valid in Lithuania and the EU countries standard methodology. Calorific value $\left(\mathrm{KJ}^{\mathrm{kg}} \mathrm{kg}^{-1}\right)$ of the investigated pellets was determined by a IKA C 5000 calorimeter (IKA, Germany) by the standard methodology (BS EN 14918:2009), the ash content - according to LST EN 14775:2010 standard.

Limit values of emissions while burning the pellets in the low power $(10 \mathrm{~kW})$ boiler were determined. Harmful emissions: $\mathrm{CO}, \mathrm{CO}_{2}$ and $\mathrm{NO}_{\mathrm{x}}$ were evaluated by using the standard methodology [17].

Analysis of variance (ANOVA) was performed for three replications by employing the $\mathrm{F}$ test and LSD (at $95 \%$ probability level) to assess significance [18].

\section{Results and discussion}

\section{Plant chopping and milling quality}

Fractional composition of the mass fractionated by a drum chopper was determined using sieves with holes of different diameters under the methodology commonly used in the EU countries. The fractional composition of plant waste of the threshed beans is presented in Table 1.

Table 1

Fractional composition of the produced chaff of fodder bean harvesting and threshing waste

\begin{tabular}{|c|c|c|c|c|c|c|c|c|c|}
\hline \multirow{2}{*}{\multicolumn{2}{|c|}{$\begin{array}{c}\text { Type of } \\
\text { plant, } \\
\text { moisture } \\
\text { content, \% }\end{array}$}} & \multicolumn{8}{|c|}{ Fraction remaining on the sieve, $g$ and \% } \\
\hline & & \multirow{2}{*}{$\begin{array}{c}\boldsymbol{\emptyset ~ 0} \\
\mathbf{m m}\end{array}$} & \multirow{2}{*}{$\begin{array}{c}\begin{array}{c}\boldsymbol{\emptyset} \mathbf{1} \\
\mathbf{m m}\end{array} \\
20.80 \\
\end{array}$} & \multirow{2}{*}{$\begin{array}{c}\begin{array}{c}\text { Ø } 3.15 \\
\mathbf{m m}\end{array} \\
59.80 \\
\end{array}$} & \multirow{2}{*}{$\begin{array}{c}\begin{array}{c}\boldsymbol{\emptyset} 8 \\
\mathbf{m m}\end{array} \\
78.10 \\
\end{array}$} & \multirow{2}{*}{$\begin{array}{c}\begin{array}{c}\boldsymbol{O} \mathbf{1 6} \\
\mathbf{m m}\end{array} \\
21.30\end{array}$} & \multirow{2}{*}{$\begin{array}{c}\begin{array}{c}\boldsymbol{0} \mathbf{4 5} \\
\mathbf{m m}\end{array} \\
1.00 \\
\end{array}$} & \multirow{2}{*}{$\begin{array}{c}\begin{array}{c}\text { Ø } 63 \\
\mathbf{m m}\end{array} \\
15.70 \\
\end{array}$} & \multirow{2}{*}{$\begin{array}{l}\text { Amount } \\
200.00\end{array}$} \\
\hline \multirow{4}{*}{$\begin{array}{c}\text { Fodder } \\
\text { bean } \\
\text { waste } \\
(9.1 \%)\end{array}$} & $\mathrm{g}$ & & & & & & & & \\
\hline & $\%$ & 1.65 & 10.40 & 29.90 & 39.05 & 10.65 & 0.50 & 7.85 & 100.00 \\
\hline & $\mathrm{g}$ & 3.60 & 19.50 & 58.50 & 73.50 & 22.30 & 1.30 & 21.30 & 200.00 \\
\hline & & 1.80 & 9.75 & 29.25 & 36.75 & 11.15 & 0.65 & 10.65 & 100.00 \\
\hline $\begin{array}{c}\text { An } \\
\text { average } \\
\text { with the } \\
\text { error }\end{array}$ & $\%$ & $\begin{array}{c}1.73 \\
\pm 0.32\end{array}$ & $\begin{array}{l}10.08 \\
\pm 1.40\end{array}$ & $\begin{array}{l}29.58 \\
\pm 1.40\end{array}$ & $\begin{array}{l}37.90 \\
\pm 4.94\end{array}$ & $\begin{array}{l}10.90 \\
\pm \quad 1.08\end{array}$ & $\begin{array}{c}0.58 \\
\pm 0.32\end{array}$ & $\begin{array}{c}9.25 \\
\pm \quad 6.02\end{array}$ & - \\
\hline
\end{tabular}

The results of the fractional composition analysis of the produced chaff (Table 1) have shown that the largest fraction of produced vegetable waste chaff accumulated on the sieves with holes of 3.15 and $8 \mathrm{~mm}$ diameter is $29.6-37.9 \%$ (this is an average fraction). A relatively large fraction was found on the sieve with 1.0 and $16 \mathrm{~mm}$ diameter holes - 10.1-10.9\%. The smallest part of fraction accumulated on the sieve with $45 \mathrm{~mm}$ diameter holes is $0.58 \%$. The resulting dust content (particle size up to $1.0 \mathrm{~mm}$ ) is small, amounting to $1.73 \%$ of the total mass of the sample. The results of these studies show that the fraction of bean waste chopped by the drum chopper is quite large, and it needs to be further chopped to flour fraction.

The main characteristics of bean flour ground by the "Retsch SM 200" mill, i.e. the fractional composition and moisture content, have been determined by the experimental research. The results of these studies are presented in Table 2.

Table 2

Fractional composition of the produced chaff of fodder bean harvesting and threshing waste

\begin{tabular}{|c|c|c|c|c|c|c|}
\hline \multirow{2}{*}{$\begin{array}{c}\text { Type of plant, } \\
\text { moisture } \\
\text { content, } \%\end{array}$} & \multicolumn{6}{|c|}{ Fraction remaining on the sieve, $g$ and \% } \\
\hline & $\begin{array}{c}\emptyset 2.0 \\
\mathbf{m m}\end{array}$ & $\begin{array}{l}\varnothing 1.0 \\
\text { mm }\end{array}$ & $\begin{array}{c}\varnothing 0.63 \\
\mathrm{~mm}\end{array}$ & $\begin{array}{c}\emptyset 0.5 \\
\mathrm{~mm}\end{array}$ & $\begin{array}{c}\varnothing 0.25 \\
\text { mm }\end{array}$ & $\begin{array}{l}\emptyset 0 \\
\text { mm }\end{array}$ \\
\hline $\begin{array}{c}\text { Fodder bean waste } \\
(9.1 \%)\end{array}$ & $\begin{array}{c}0.01 \\
\pm 0.01\end{array}$ & $\begin{array}{c}34.8 \\
\pm 11.2\end{array}$ & $\begin{array}{l}18.7 \\
\pm 3.9\end{array}$ & $\begin{aligned} & 7.6 \\
\pm & 2.2\end{aligned}$ & $\begin{array}{l}21.7 \\
\pm 4.3\end{array}$ & $\begin{array}{l}17.2 \\
\pm 3.4\end{array}$ \\
\hline
\end{tabular}


The research on the fractional composition of the milled bean waste (Table 2) has disclosed that the largest fraction of vegetable waste fraction accumulates on the sieve with holes of $1.0 \mathrm{~mm}$ diameter - it is $34.8 \%$ (it is a sufficiently large fraction). A large amount of flour fraction is also found on the sieves with holes of $0.25 \mathrm{~mm}$ diameter $(21.7 \%)$ and the ones with holes of $0.63 \mathrm{~mm}$ diameter $(18.7 \%)$, indicating a fraction of medium size. The smallest part of the fraction accumulates on a sieve with holes of $0.01 \mathrm{~mm}$ diameter, the amount of fine dust-particle (up to $1.0 \mathrm{~mm}$ ) accounts for $17.2 \%$ of the total sample mass. The results of these studies indicate that the quality of bean waste flour chopped by the hummer mill is suitable for pelleting.

The moisture content of bean waste flour was similar to that of the produced chaff, as it was not dried further before cutting. The measured flour moisture content was suitable for pelleting and was equal to $9.1 \%$.

\section{Pellet physical-mechanical properties}

The following biometric and physical-mechanical properties of crushed bean processing waste pellets were determined: dimensions, mass, moisture, volume and packed density. The tests were carried out at the ASU laboratories.

The results of the tests of the pellet properties - moisture and biometric properties, such as dimensions, volume, mass and calculated density - are given in Table 3.

Biometric properties and density of pellets

Table 3

\begin{tabular}{|c|c|c|c|c|c|}
\hline \multirow{2}{*}{$\begin{array}{c}\text { Type of plant, } \\
\text { moisture content, } \%\end{array}$} & \multicolumn{5}{|c|}{ Parameters and density of granules } \\
\hline & $\begin{array}{c}\text { Length } l, \\
\text { mm }\end{array}$ & $\begin{array}{c}\text { Diameter } \varphi, \\
\mathbf{m m}\end{array}$ & $\begin{array}{c}\text { Volume, } \\
\mathbf{m}^{3}\end{array}$ & Ma & Den \\
\hline $\begin{array}{c}\text { Fodder bean waste } \\
w=8.67 \pm 0.26\end{array}$ & $\begin{array}{l}24.32 \\
\pm 1.96\end{array}$ & $\begin{array}{c}5.99 \\
\pm 0.08\end{array}$ & $\begin{array}{l}6.84 \cdot 10^{-7} \\
\pm 0.56\end{array}$ & $\begin{array}{l}0.98 \\
\pm 0.06\end{array}$ & $\begin{array}{c}1435.89 \pm 70.81 \\
1311.40 \pm 64.67 \mathrm{DM}\end{array}$ \\
\hline
\end{tabular}

The results of the performed studies (Table 3 ) show that moisture of bean waste pellets is equal to $8.67 \pm 0.26 \%$. The determined density of the produced granules (dry materials) reaches as much as $1.311 .40 \pm 64.67 \mathrm{~kg} \cdot \mathrm{m}^{-3}$. The obtained densities of solid pellets are large enough to satisfy the requirements for granular biofuel $\left(1.000-1.200 \mathrm{~kg} \cdot \mathrm{m}^{-3}\right)$.

After analysing the biometric properties of bean waste granules, it has been found that high quality, sufficiently strong and dense granules with horizontal matrix milled to the flour fractions of 1$2 \mathrm{~mm}$ and pressed with a granulator are obtained. A rather high density of bean waste granules is found, which is equal to $700.3 \pm 33.0 \mathrm{~kg} \cdot \mathrm{m}^{-3}$.

\section{Pellet thermal properties}

The results of the calorific value and ash content studies of pelleted bean waste are presented in Table 4.

Table 4

Calorific value and ash content of bean waste granules

\begin{tabular}{|c|c|c|c|c|}
\hline Type of plant & $\begin{array}{c}\text { Moisture } \\
\text { content, \% }\end{array}$ & $\begin{array}{c}\text { Ash } \\
\text { content, \% }\end{array}$ & $\begin{array}{c}\text { Upper calorific } \\
\text { value of dry fuel, } \\
\mathbf{M J} \cdot \mathbf{k g}^{-\mathbf{1}}\end{array}$ & $\begin{array}{c}\text { Lower calorific } \\
\text { value of dry fuel, } \\
\mathbf{M J} \cdot \mathbf{k g}^{-1}\end{array}$ \\
\hline $\begin{array}{c}\text { Fodder bean } \\
\text { waste }\end{array}$ & $8.93 \pm 0.07$ & $3.93 \pm 0.11$ & $18.17 \pm 0.28$ & $17.0 \pm 0.32$ \\
\hline
\end{tabular}

The resulting ash content of the investigated bean plant waste is $3.93 \pm 0.11 \%$, which is an average ash content. The estimated lower calorific value of dry fuel from bean waste is $17.0 \pm 0.32 \mathrm{MJ} \cdot \mathrm{kg}^{-1}$.

When comparing the average calorific values of dry fuel from bean waste, as well as other parameters, it is possible to evaluate their value among other types of used fuels [19]. The presented data make it possible to conclude that the total energy value of bean waste with a lower calorific value reaching $17.0 \mathrm{MJ} \cdot \mathrm{kg}^{-1}$ is close to the mass of herbaceous waste (straw, road grass). The herbal mass 
(straw, road grass) has lower energy content than other types of fuels. Wood has a higher energy value than vegetable waste. Birch, which is considered a benchmark for solid biofuels in many countries, has a lower calorific value of dry fuel of $19.3 \mathrm{MJ} \cdot \mathrm{kg}^{-1}$ [19], which is approximately $2.3 \mathrm{MJ} \cdot \mathrm{kg}^{-1}$ more than that of the bean processing waste.

After evaluation of harmful gas emissions of fodder bean waste pellets, it was determined that the harmful emissions to the environment burning bean waste pellets did not exceed the permissible values, and the environment was minimally polluted. Determined gas concentration of carbon monoxide (CO) was 1900-2020 ppm, gas concentration of carbon dioxide $\left(\mathrm{CO}_{2}\right)$ varied from 4.1 to $5.2 \%$, and harmful gas emissions of nitrogen oxide $\left(\mathrm{NO}_{\mathrm{x}}\right)$ varied from 146.1 to $164.1 \mathrm{ppm}$. Sulphur dioxide $\left(\mathrm{SO}_{2}\right)$ gas emissions from combustion of the investigated fodder bean waste pellets were not recorded.

To sum it all up, it may be concluded that usage of fodder bean waste pellets for biofuel is justified very well because its main parameters satisfy the requirements for high quality solid biofuels.

\section{Conclusions}

1. There were investigated the technological-technical parameters of fodder bean waste preparation for granulated solid biofuel and the produced pellet utilization for energy purposes. For pellet production, the plant mill was granulated by a small capacity $\left(80-120 \mathrm{~kg} \cdot \mathrm{h}^{-1}\right)$ granulator with a horizontal granulator matrix; the diameter of the pellets was $6 \mathrm{~mm}$.

2. Before the pellets were produced, the fodder bean waste was chopped and milled , and the plant mass chaff and mill quality indicators were investigated: the fractional composition and moisture content. The research in the fractional composition of the milled bean waste has disclosed that the largest fraction of vegetable waste fraction accumulates on the sieve with holes of $1.0 \mathrm{~mm}$ diameter - it is $34.8 \%$.

3. After pellet production, the physical-mechanical and thermal properties of the investigated fodder bean waste pellets were determined and presented: the moisture content, density, ash content and pellet calorific value. The pellet moisture content varied from $8.9 \%$ to $9.8 \%$, and pellet density was very high and reached $1311.40 \pm 64.67 \mathrm{~kg} \cdot \mathrm{m}^{-3} \mathrm{DM}$ (dry matter).

4. The determined ash content of the investigated fodder bean plant waste varied from 3.9 to $7.0 \%$. The estimated lower calorific value of dry fuel from bean waste is $17.0 \pm 0.32 \mathrm{MJ} \cdot \mathrm{kg}^{-1} \mathrm{DM}$. These presented data show that the total energy value of bean waste with the determined lower calorific value is close to the mass of other herbaceous plant waste.

5. After evaluation of harmful gas emissions, it was determined that the harmful emissions to the environment, when burning bean waste pellets, did not exceed the permissible values. The received concentration of carbon monoxide was 1900-2020 ppm; quantity of carbon dioxide was 4.1-5.2\%; emissions of nitrogen oxide reached 146.1-164.1 ppm; sulphur dioxide gas emissions were not recorded.

\section{References}

[1] Jungtinių Tautų 70-ta sesija Generalinès Asamblëjos rezoliucija „Keiskime mūsų pasaulį” (,Replace our World”). 2015 m. rugsejjo 25 d. (In Lithuanian).

[2] FAOSTAT. Food and Agriculture Organization of the United Nations. Rome, Italy. Available online at: http://www.fao.org/faostat/en/\#data. (Accesed 20.01.2018).

[3] Topal N., Bozoglu H. "Some plant properties interactions and 1-dopa content of faba bean (vicia faba 1.) That different sowing time". VII International Scientific Agriculture Symposium "Agrosym 2016".

[4] Statistikos departamentas. Vilnius, Lietuva. https://osp.stat.gov.lt/statistiniu-rodikliu-analize\#/ (Accesed 21.01.2018).

[5] Kolisnyk S., KobakInoculation S. Inoculation as an element of energy saving in the cultivation technology of grain legumes under conditions of the forest-steppe of Ukraine. Proceedings of the international scientific conference "Renewable energy and energy efficiency". 2012, Jelgava, Latvia, pp. 29-32. 
[6] Zvicevičius E., Raila A., Novošinskas H. Augalinės biomasės sandèliavimo sistemų inžinerija: mokomoji knyga (Vegetable biomass storage systems engineering: instructional book). Akademija, Kauno r. 2013. p. 10. (In Lithuanian).

[7] Jasinevičius G. Darnaus vystymosi strategija ir praktika / mokslo darbai. Medienos ir agrobiokuras (Sustainable Development Strategy and Practice / Scientific Works. Wood and agro biofuels). Lietuvos Respublikos aplinkos ministerijos Miškų departamentas. Vilnius. Mykolo Romerio Universitetas. 2011, p. 145 (In Lithuanian).

[8] United Nations Environmental Programme. Technologies for Converting Waste Agricultural Biomass to Energy. 2013.

[9] Pastre O. Analysis of the technical obsticalse related to the production and utilization of fuel pellets made from agricultural residues / EUBIA. Pellets for Europe ALTENER 2002-012-137160. $59 \mathrm{p}$.

[10] Jasinskas A., Scholz V. Augalų biomasès nuėmimo ir ruošimo kurui technologijos ir jų vertinimas: studija (Evaluation of technologies of plant biomass harvesting and preparation for fuel: coursebook). Raudondvaris, Lietuva, 2008, 74 p. (In Lithuanian).

[11] Protić M., Mitić D., Stefanović V. Wood pellets production technology. International Conference Safety of Technical Systems in Living and Working Environment, 2011.

[12] Jasinskas A., Simonavičiūtė R., Šiaudinis G., Liaudanskienė I., Antanaitis Š., Arak M., Olt, J. The assessment of common mugwort (Artemisia vulgaris L.) and cup plant (Silphium perfoliatum L.) productivity and technological preparation for solid biofuel. Zemdirbyste-Agriculture, 2014, 101(1), pp. 19-26.

[13]DD CEN/TS 15149-1:2006. Solid biofuels - Methods for the determination of particle size distribution. Part 1: Oscillating screen method using sieve apertures of $3.15 \mathrm{~mm}$ and above. 2006.

[14] Streikus D., Jasinskas A., Arak M., Jotautienė E., Mieldažys R., Čekanauskas S., Jankauskienė Z. Investigations of fibre plants preparation and utilization of solid biofuels. Agronomy Research, 2016, Vol. 14, No 1, pp. 259-268.

[15]CEN/TC 14774-1:2005. Solid biofuels - Methods for the determination of moisture content Oven dry method - Part 1: Total moisture - Reference method. 2005.

[16] Niedziołka I., Szpryngiel M., Kachel-Jakubowska M., Kraszkiewicz A., Zawislak K., Sobczak P., Nadulski R. Assessment of the energetic and mechanical properties of pellets produced from agricultural biomass. Renewable Energy, 2015, 76, pp. 312-317.

[17] Šiaudinis G., Jasinskas A., Šarauskis E., Steponavičius D., Karčiauskienė D., Liaudanskienė I. The assessment of Virginia mallow (Sida hermaphrodita Rusby) and cup plant (Silphium perfoliatum L.) productivity, physico-mechanical properties and energy expenses. Energy, 2015, Vol. 93, part 1, pp. 606-612.

[18] Tarakanovas P., Raudonius S. Statistical analysis of agronomical research data with computer programs ANOVA, STAT, SPLIT-PLOT from packet SELEKCIJA and IRRISTAT. Lithuanian University of Agriculture, 2003, 58 p. (in Lithuanian).

[19] Vares V., Kask U, Muiste P., Pihu T., Soosaar S. Biokuro naudotojo žinynas (Biofuels User's manual). Vilnius, 2007, 188 p. (In Lithuanian). 